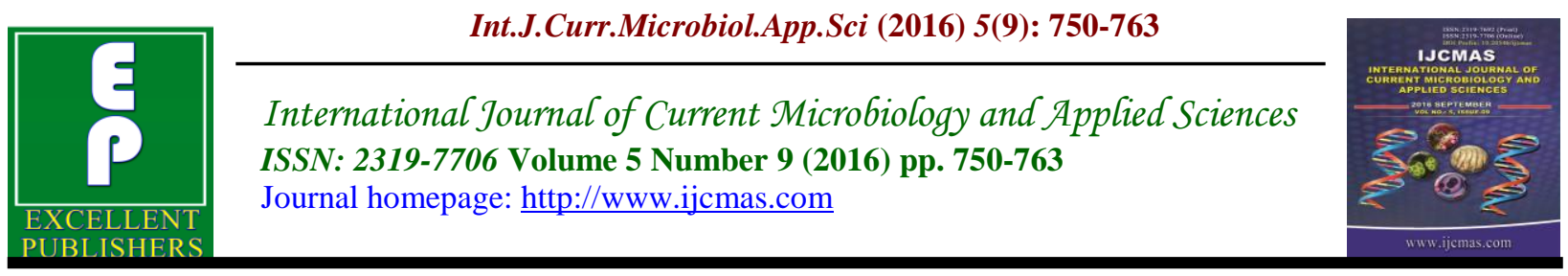

Original Research Article

http://dx.doi.org/10.20546/ijcmas.2016.509.086

\title{
The Effect of Fungi Inoculation Solvent Phosphate in Increasing Phosphorus availability in Calcareous Soil and its Concentration in Cucumis sativus L.
}

\author{
Haider A. Fadhl* and Bahaa A.A. Al-Hadithi \\ Soil sciences and water Resources, College of Agriculture. University of Baghdad, Iraq \\ *Corresponding author
}

\section{Keywords}

Trichoderma fungi, Aspergillus fungi, organic material, Rock Phosphate.

Article Info Accepted: 28 August 2016 Available Online: 10 September 2016

\section{A B S T R A C T}

Field experiment of three factors was carried out in side plastic house using sicl soil with sun sterilization used RCBD design experiment included 36 units resulting from the combination of Bio fertilizer of tow treatment the first was $\mathrm{T}$ (Trichoderma fungi) and the second was A (Aspergillus fungi), organic material with two treatment OM1 (odd O.M.) and OM0 (without organic material ), supper phosphate fertilizer TSP (triple supper phosphate) and ROC (Rock phosphate) several isolates of fungus. Trichoderma and Aspergillus specializing in dissolving phosphorus $\mathrm{T}$ and $\mathrm{A}$ fungi were tested by their capacity to made halo zone around the colonies as a result of dissolving phosphorus on solid media. The results shown there significant increase in the content of the shoot of phosphorus reaching the highest values in the middle of the season when add bio fertilizer dual element phosphorus $(0.29-0.33 \%)$ for the treatment of TSP with addition organic material and $(0.29-0.25) \%$ for the treatment TSP and Rock phosphate without organic material .The addition of fungal bio fertilizers are single or double gave or led to a significant increase in the soil content of available phosphorus reaching the high value in the first period of growth (mid season) when add dual bio fertilizer (50.16 -46.08) $\mathrm{m} \mathrm{gm} \mathrm{p} \mathrm{kg}^{-1}$ of soil for TSP and Rock phosphate treat in the presence of organic material while we get $(47.21-43.20) \mathrm{mgm} \mathrm{p}^{-\mathrm{kg}^{-1}}$ of soil Tsp and Rock phosphate without organic material addition.

\section{Introduction}

Increasing world population is one of the big challenges facing the UN and governments in the food and living requirements of the provision. So that it must be increase the voltage efforts to provide food through increased agriculture production and this requires the expansion of the production of the production process in the vertical and horizontal direction -Limestone soil suffer from a lock of phosphorus elements it is one of the main plant growth nutrients phosphorus in soils world in varying amounts of soil to the other and have high concentration in fertile agricultural land than in agricultural soils. Soils differ in their content of phosphorus depending on the parent material and organic material and natural processes ongoing in which texture and soil old soil Al-Naimi, 1999. Phosphorus concentration in the plant 
between (0.1-0.4)\%, while in the soils is up (0.02-0.15)\% Williams, 1959. Amedei, 2000 mentioned that when you add any fertilizer phosphate to the limestone soil, this added Lead to reactions the first is the adsorption of phosphorus after the liberation of fertilizer sources but the second is sedimentation depending on the solubility product. Adsorption can be defined as the interaction between physiochemical reaction ions and surfaces minutes external and internal clay thus become Less ready for update by plant root, also adsorption phenomenon affecting the availability of phosphorus to plant through its focus which falls in the soil solution Amedei, 2000. Phosphorus sedimentation gained much attention in recent years, particularly in calcareous soils because they are important to know the fate of phosphate fertilizers added to the soil. Both Amedei, 2000 that structure calcium phosphate is controlling the solubility of phosphorus in soil and transformed overtime in to phosphorus formula eight calcium Hoflichatal, 1994. People had high attention to know soil Microbiology since the dawn of history, so it was a fungi iced large share of this interest and that because of the large sites. and play a significant role in the biological control of plant diseases. and has a great role in increasing the Solubility and the uptake plant root Fadoul and Nafa, 2009. Aspergillus fungus include 50 genus and several hundred species, alive suprophyta in the soil on organic material and is widespread in nature, these fungi multiply asexually producing chains of spores named conidiospores carry on conidiophare. Types here wide attention of scientists and specialists to be used in the production of antibiotics and organic acids of these fungus which increases and improve plant growth through their role in element cycles in nature, such as nitrogen, phosphorus, potassium, Iron, sulfur (Fadool and Nafa, 2009). Gender has called Aspergillus by Antonio Micheli (1679 1736) issued in (1727)entitled Nova plant arum. Trichoderma fungus missing throws living and used as fertilizer vital through some metabolic secretions of this fungus, which increase plant growth through its role in element cycles in nature such as nitrogen, phosphorus and potassium. Itis also used in the field of biological control against Certain pathogens that in fact agricultural crops.

\section{Materials and Methods}

Samples were collected from several areas in central of Iraq from 0-30 cm depth and then placed in Sterile bags of poly ethylene. Samples are numbered and each number represent the place of sampling, type of plant grown \& date of sampling. Soil bags were take out to the lab and mixed well and took $600 \mathrm{gm}$ of soil for the purpose of isolating fungi, series of soil dilution were prepared for the purposes of is fungi to inoculate specialist media (CzapekDox Agar) which prepared and sterilized. By Auto clave for 15 minutes and at a temperature of $121 \mathrm{c}$ and 13 pounds pressure. the media were put in Petridishes and in cubated at a temperature $28 \mathrm{c}$ for 5-7 days period after that examined dishes Observation the growth Culture which was diagnosed at a center of surface media, which is a positive sign for the growth of fungi. purification fungal obtained by taking part of coloni growth clearly by loop to the Petridish containing CzapekDox Agar media and repeated the operation there time to get a pure culture. thus are ready to test any of them on dissolving phosphorus on solid media for each type of these fungi on Specialized food circles Containing phosphorus (Agar media) 
Nautiyal, 1999) also used two medium PVK (pikovskay,1948) and NBRIP (Mehta and Nautiyal, 2001). The dishes are placed in the incubator at a temperature of $28 \mathrm{c}$ where the follow -up of fungal colonics diameter during six days before fill a petri dish fungal. Experiment carried out for each fungal isolates to measure (ST) Solubilization index values based on the ratio of total diameter of colony (Colony+ halo zone) to colony diameter (Edi-premono et al., 1996) preparation of inoculum (vaccines) fungal which include both (Aspergillus niger and Trichoderma) Through the preparation of bags made of thermal capacity of on $\mathrm{kg}$ Containing $500 \mathrm{gm}$ of peat moss and $15 \mathrm{gm}$ of wheat and $50 \mathrm{~cm}^{3}$ distilled water with addition of $0.5 \mathrm{gm}$ sugar Glucose and sterilized at a temperature 121c and 15pounds pressure for 20 minutes and then cooled and placed in the incubator for two days at a temperature $28 \mathrm{c}$ this process repeated three time and then added to the bagspart of the Agriculture fungal (7 tablet by. cork piercing) and placed there in incubator for six days. Density of thevaccine (inoculum) estimated before adding it to the soil. The inoculum of fungi add to the soil eight days before planting for the purpose of giving the fungal opportunity to growth and Formation colonica and hyphae around the root tone or in the rhizosphere. The experiment was performed by preparing the soil in the plastic house or a green house and solar pasteurization and plowing, made terracing for cultivation of the plant option. Then were open each bench inside the middle also Fertilizer were added according the re commended amount of plant option which were $(150 \mathrm{~N}, 250 \mathrm{P}, 320 \mathrm{~K}) \quad \mathrm{kg} \cdot \mathrm{ha}^{-1}$. The seeds planted option class (SAMART) spanish company by 12 seed in each experimental unit after sterilized by sodium hypochlorite (1\%) and then with ethyl alcohol95\%. Seeds washed with distilled water there time after sowing seeds to 6 seedling in each experiment unit.

\section{Results and Discussion}

Results in table 2, showed significant differences among fungal isolates tested in diameter rate values of halo zone around colonies which were $1.78 \mathrm{~cm}$ and $1.03 \mathrm{~cm}$ for A1 and A2 isolates respectively. Trichoderma fungus also has ability to dissolve phosphorus in the solid media, which formed a halo (Aura) transparent around colonics of fungus but the highest value was $0.84 \mathrm{~cm}$ and $0.69 \mathrm{~cm}$ for $\mathrm{T} 1$ and T2isolatesrespectively. There were significant differences in the ability of fungus to form halo zone on solid media which were 0.84 to 0.79 and $0.64 \mathrm{~cm}$ for PVK, NBRIP and NBRIY media respectively. Aspergillus fungus showed high ability to soluble phosphorus on solid media reaching the highest index (SI) of $2.06 \mathrm{~cm}, 1.76$ and $1.53 \mathrm{~cm}$ for A1 isolate on Solid media PVK,NBRIP and NBRIY respectively and A2 was 1.16, 1.06 and 0.86 $\mathrm{cm}$ on the same solid media respectively, while Trichoderma fungal SI values was $1.06 \mathrm{~cm}, 0.09 \mathrm{~cm}$ and $0.56 \mathrm{~cm}$ for $\mathrm{T} 1 \mathrm{on}$ solid media PVK, NBRIP and NBRIY respectively whitelaw,2000 saber,2009 Kumari,2008 panda at all,2008 yadav,2011 Harman, 2000.The results showed the ability of isolated fungal samples to increase the solubility of phosphorus in the sold circles of food. Two types of fungal (Aspergillus \& Trichoderma) were distinguished by a high capacity for soluble phosphorus. Also these two samples differ in their ability of solubility of phosphorus Alikhani et al., 2006. As Whitelaw 2000 mentioned that the deposition of phosphorus in a solid food environment useful in isolating microorganisms and testing it. These results 
agreed with the one of Saber et al., 2009. Where the isolation of the fungus Aspergillus niger ability to form transparent zone around the colonies and solid food center NBRIP shown, this indicates its ability to dissolve phosphorus.It was reported by Illmer et al., 1995 that the fungus Aspergillus niger knew outstanding secretion organic acids as well as the composition of the halo transparent is discolored.The ability of these isolates were tested and fungal on the composition of the halo transparent, which is evidence of the increased solubility of phosphorus back to the secretion of organic acids and lead reduced $\mathrm{pH}$ center from Formicum, Maleic, Citric acid \& oxalic acid Kumari et al., 2008. Or secretion of enzymes such as enzyme Phytase and PhosPatases that increase the level of phosphorus dissolved in poor soils and increase the plant's resistance to conditions unsuitable Panda et al., 2011. Yadav et al., 2011 have pointed that A. niger fungal is one of the best fungus phosphate dissolving. There are a lot of studies that confirm the fungus Trichoderma is destined to increase the readiness of phosphorus by dissolving compounds containing phosphorus element through.in Tables 3 and 4 results showed that the addition of bio inoculum achieved option of total phosphorus content reaching phosphorus ratios in the middle of season $0.16 \%, 0.20 \%$ and $0.29 \%$ for T, A and AT respectively, while AT was significant also the percentages $0.14,0.16$ and $0.25 \%$ for treatment $\mathrm{T}, \mathrm{A}$ and $\mathrm{AT}$ respectively. AT treatment excelled significant Compared with A and Tin this line with May et al., 2013 and Turan et al., 2007on wheat crop. These results confirm increase the availability of phosphorus by dissolving compounds containing phosphorus through mechanisms mentioned by $\mathrm{Al}$ altomare et al., 1999; Harman, 2000 Suchas acidification of Rhizosphere or production of metabolic compounds such as chelating agent and growth regulators such al gibberellin (alsamarrai, 2002), which improved plant growth and give root strength and density and then be able to uptake nutrients such as phosphorus also these results showed the ability of Aspergillus fungus to increase the availability and soluble phosphorus by dissolving compounds containing phosphorus element through product acidic compound such as citric and formic, malic succinic acid (Kumari et al., 2008; Rajanka et al., 2007) or the activity of oxidation and reduction potential Hamza et al., 2012 or Secretion of enzymes such as phosphatase enzyme that increase the availability of phosphorus to plant uptake saber et al., 2009; Achal, 2005; Deepa et al., 2010. In addition the production of growth regulators such as gibberellic and indoleacitic acid yadav et al., 2011 which improves the growth and give the total radical dense unable to uptake nutrient phosphorus. The addition of phosphorus fertilizer lead to an increase in content of the shoot of plant of the total phosphorus in the mid-season $(0.20 \%$ to $0.24 \%)$ for treatment ROK and TSP respectively, where the superiority of triple superphosphate fertilizer significantly on Rock phosphate either at the end of the season was phosphorus ratios in the shoot to plant $0.17 \%$ and $0.19 \%$ also have the option outweigh the superiority of super phosphate fertilizer triple availability on the rock phosphate though triple superphosphate high solubility compared with rock phosphate and will be available in the soil more that Rock phosphate This was reflected in turn increase the phosphorus uptake by the roots of plant where the phosphorus to strengthen and revitalize root system of plants and thus works to increase the absorption of nutrients such as phosphorus Havlin et al., 2005 on the results approach also in table 3,4 the addition of organic material significant increase in the content of the shoot of plant 
option of phosphorus element reaching rates in the middle of season to $0.20 \%$ and $0.23 \%$ for transactions OM0 and OM1 respectively compared without organic material addition This increase in due to the content of shoot of a plant uptake phosphorus to contain organic material on the phosphorus and the role of organic fertilizer to increase the readiness of nutrient suchas phosphorus Havlin et al., 2005. The increases of phosphorous with adding organic fertilizer level will be results of increase phosphorous enter the plant tissue. Interaction between Biofertilizer and phosphate showed a significant increase in the content of vegetative plant phosphorus reaching in middle of growing season $0.15 \%, 0.18 \%$, $0.27 \%, 0.18 \%, 0.21 \%$ and $0.31 \%$ for treatment T ROK,AROK, AT ROK, T TSP, A TSP and AT TSP respectively. Either at the end of season results showed and reaching $0.12 \%, 0.15 \%, 0.24 \%, 0.15 \%$, $0.18 \%, 0.25 \%$, for treatment $\mathrm{T}$ ROK, A ROK, AT ROK, T TSP, A TSP and AT TSP respectively m Vaddar, 2007, Richa et al., 2007; Yadav et al., 2011; penda et al., 2011; ALzendiagn, 2011; Kamari et al., 2008; Yalda, 1995; Khan, 2011). Triple interaction among biofertilizer, organic material and phosphate fertilizer increased significantly in the content of the shoot of plant of phosphorus reaching rates in the middle of season $0.25 \%, 0.29 \%, 0.29 \%$, $0.33 \%$, for ATOM0 ROK, AT OM1 ROK, AT OM0 TSP and AT OM1 TSP respectively. Treatment AT OM1 TSP was significant outperforming on the treatment (AT OM1ROK) and also there was significant difference between the two treatments AT OM0 ROK and AT OM1 TSP. In the same approach end of season, the ratios $0.11 \%, 0.13 \%, 0.14 \%$, and $0.16 \%$, of treatment AT OM0 ROK, AT OM1 ROK, AT OM0 TSP and AT OM1 TSP respectively. The Cause of increased phosphorus in the shoot of a plant during the duration of plant growth is a result of the positive interaction between fungus Aspergillus niger and Trichoderma. the results increase the activity of fungi to the end of season of this plant growth returns to the role of positive interaction between Microorganisms and organic material and the presence of as source of phosphorus where the fungus enzymes and organic acids and ion exchange processes these processes lead to vacillate and increase the solubility of phosphorus (youssif et al., 2013).

Results showed in tables 5 and 6 that bio fertilizer gave significant impact in increasing the soil content of phosphorus available reaching in the middle of season $31.43 \mathrm{mg}$ p. kg soil ${ }^{-1}, 39.31 \mathrm{mg} \mathrm{p.} \mathrm{kg} \mathrm{\text {soil } ^ { - 1 }}$

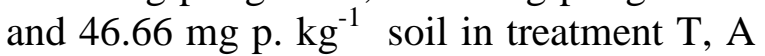
and AT respectively while AT treatment superior on $\mathrm{A}$ and $\mathrm{T}$ treatment significantly as well as treatment A superior significantly on $\mathrm{T}$ treatment at the end of the season reaching 22.40, 27.64 and $37.28 \mathrm{mg} \mathrm{p.} \mathrm{kg}^{-1}$ soil for T,A and AT treatment respectively promwee et al., 2014; qasim and ALzendiagn, 2011 on corn crop. This result confirms the ability of fungi to increase the solubility and availability of phosphorus by dissolving compounds containing phosphorus element available from organic and Lower $\mathrm{pH}$ soils such as citric acid, formic, malic acid Kumari and others, 2008 and Lactic, citric, succinic acid Li et al., 2015. or secretion of enzymes such as phytase and phosphate that increase phosphorus level dissolved in poor soil and increase plant condition unfavorite resistance (panda et al., 2011). Revealed the results table 5and 6 the addition of phosphate fertilizer lead to a significant increase in soil phosphorus content in the middle of season which were 37.08 and

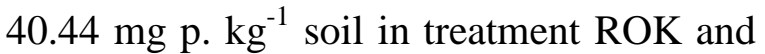
TSP respectively. Where triple super phosphate fertilizer excelled on rock 
phosphate significantly at the end of season

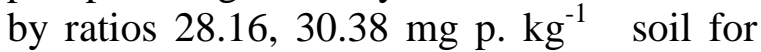
treatment ROK and TSP respectively, while triple phosphate excelled on Rock phosphate. These results approach with seshachala et al., 2012. Got with apepper plant results show increase phosphorus availability in the soil and this is due to the activity of phytase enzyme secreted by fungi and increase phosphorus solubility. The addition of organic material gave a significant increase in the phosphorus content of the reaching results in the middle

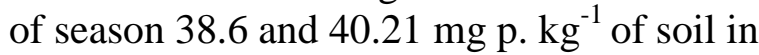
treatment OM0 and OM1 respectively out performing addition of organic material on the treatment without organic material at the end of season stood at 28.46 and 30.09 $\mathrm{mg} \mathrm{p.} \mathrm{kg}^{-1}$ of soil in treatment OM0 and OM1 respectively with significant values This mean the activity of microorganisms in the soil helped increase the solubility and absorption of phosphorus by plant roots that the addition of organic material to the soil leads to increased soil organic material, phosphorus, largely as a source of phosphorus has happened Hossney and Ahmed, 2009. on the treatment of animal fertilization Level of 5 tons an acre has excelled on the chemical fertilization in processing phosphorus mineral Rosen and Eliason, 2002. The organic wastes role in enriching the soil gas $\mathrm{CO}_{2}$ and acid and organic humic lowers the $\mathrm{pH}$ value of soil which increases the available of phosphorus added with waste and existing originally soilas well as the role of these acids in chelation ions $\mathrm{Ca}$ and $\mathrm{mg}$ and $\mathrm{AL}$ and $\mathrm{Fe}$ Leaving phosphorus Free in solution or caught phosphorus Like humus- phosphate high availability in soils of Limestone and also pecking soil particles and oxides which reduces the availability is dale and Nelson, 1975. Results showed interaction between the bio-fertilizer and phosphate fertilizer were significant increased in soil phosphorus content reaching proportions in the middle of solubility product. Adsorption can be defined as the interaction between physiochemical reaction ions and surfaces minutes external and in claythus become Less ready for aptate by plant root, also adsorption phenomenon a element nutrient the availability of phosphorus to plant through its focus which falls in the soil solution Amedei, 2000.

Table.1 Chemical and physical properties of the soil study

\begin{tabular}{|c|c|c|c|}
\hline \multicolumn{2}{|c|}{ Adjective } & value & Unit \\
\hline \multicolumn{2}{|c|}{ Soil pH reaction of 1: 1} & 7.6 & \\
\hline \multicolumn{2}{|c|}{$\begin{array}{c}\text { Electrical conductivity EC } 1: \\
1\end{array}$} & 1.4 & Decesamenz.m $^{-1}$ \\
\hline \multicolumn{2}{|c|}{ CEC } & 25 & \multirow{4}{*}{$\begin{array}{c}\text { Milli-equivalent / } 100 \mathrm{~g} \\
\text { soil } \\
\%\end{array}$} \\
\hline \multicolumn{2}{|c|}{ Organic material } & 0.81 & \\
\hline \multicolumn{2}{|c|}{ Gypsum } & 0.003 & \\
\hline \multicolumn{2}{|c|}{ Lime } & 48.25 & \\
\hline \multicolumn{2}{|c|}{ Calcium $\mathrm{Ca}^{+2}$} & 2.1 & \multirow{5}{*}{$\begin{array}{c}\text { Cynthia Mul.cgm }^{-1} \text { soil } \\
1: 1\end{array}$} \\
\hline \multicolumn{2}{|c|}{$\mathrm{Mg}^{+2}$} & 1.1 & \\
\hline \multicolumn{2}{|c|}{ Bicarbonate $\mathrm{HCO} 3$} & 1.5 & \\
\hline \multicolumn{2}{|c|}{ Sodium $\mathrm{Na}+$} & 2.1 & \\
\hline \multicolumn{2}{|c|}{ Chlorine $\mathrm{Cl}^{-1}$} & 1.9 & \\
\hline \multirow{3}{*}{$\begin{array}{l}\text { availableEl } \\
\text { ements }\end{array}$} & Nitrogen & 32 & \multirow[t]{3}{*}{ PPM } \\
\hline & Phosphorus & 11 & \\
\hline & Potassium & 172 & \\
\hline \multicolumn{2}{|c|}{ Texture } & \multicolumn{2}{|c|}{ Silt Clay Loam } \\
\hline
\end{tabular}


Table.2 Viability of fungal isolates to dissolve phosphorus element in the solid food environment Solid food environment

\begin{tabular}{|c|c|c|c|c|}
\hline $\begin{array}{c}\text { Media Food } \\
\text { Isolation Fungal }\end{array}$ & PVK & NBRIP & NBRIY & $\begin{array}{c}\text { Mean of } \\
\text { halozone } \\
\text { (cm) }\end{array}$ \\
\hline A1 ( Aspergillus) & 2.06 & 1.76 & 1.53 & 1.78 \\
\hline A2 (Aspergillus) & 1.16 & 1.06 & 0.86 & 1.03 \\
\hline A3 (Aspergillus) & 0.53 & 0.40 & 0.53 & 0.48 \\
\hline B (Fungal isolates) & 0.50 & 0.46 & 0.60 & 0.52 \\
\hline T1 ( Trichoderma) & 1.06 & 0.90 & 0.56 & 0.84 \\
\hline T2 ( Trichoderma) & 0.86 & 0.74 & 0.46 & 0.69 \\
\hline T3 ( Trichoderma) & 0.56 & 0.66 & 0.50 & 0.57 \\
\hline C (Fungal isolates) & 0.46 & 0.63 & 0.43 & 0.51 \\
\hline D (Fungal isolates) & 0.46 & 0.76 & 0.23 & 0.48 \\
\hline E (Fungal isolates) & 0.76 & 0.53 & 0.40 & 0.56 \\
\hline Mean of Agar media & 0.84 & 0.79 & 0.61 & LSD : 0.05 \\
\cline { 1 - 3 } $\begin{array}{c}\text { Mixing between fungal } \\
\text { isolates and Agar Media }\end{array}$ & Agar Media & fungal isolates & \\
\cline { 1 - 3 } & 0.080 & \multicolumn{3}{|c}{0.14} \\
\hline
\end{tabular}

Table.3 The effect of bio-fertilizers and phosphate and organic material content in the shoot of the phosphorus \% at mid-season

\begin{tabular}{|c|c|c|c|c|c|c|}
\hline $\begin{array}{c}\text { Bio- } \\
\text { fertilizer } \\
\text { (B) }\end{array}$ & $\begin{array}{c}\text { organic } \\
\text { material } \\
(\mathrm{OM})\end{array}$ & \multicolumn{2}{|c|}{$\begin{array}{l}\text { Phosphate fertilizer } \\
\text { (P) }\end{array}$} & \multicolumn{3}{|c|}{ Mean Bio-fertilizer } \\
\hline \multirow{3}{*}{$\mathbf{T}$} & \multirow[b]{2}{*}{ OMo } & ROC & TSP & \multirow{2}{*}{\multicolumn{3}{|c|}{0.16}} \\
\hline & & 0.14 & 0.17 & & & \\
\hline & OM1 & 0.16 & 0.19 & \multirow{2}{*}{\multicolumn{3}{|c|}{0.20}} \\
\hline \multirow[b]{2}{*}{ A } & OMo & 0.18 & 0.20 & & & \\
\hline & OM1 & 0.19 & 0.23 & \multirow{4}{*}{\multicolumn{3}{|c|}{0.29}} \\
\hline \multirow[b]{2}{*}{ AT } & OMo & 0.25 & 0.29 & & & \\
\hline & OM1 & 0.29 & 0.33 & & & \\
\hline \multicolumn{2}{|c|}{ Mean Phosphate fertilizer } & 0.20 & 0.24 & & & \\
\hline \multirow{2}{*}{\multicolumn{2}{|c|}{ Bio-fertilizer }} & Phosph & ertilizer & \multirow{2}{*}{\multicolumn{3}{|c|}{ Mean Bio-fertilizer }} \\
\hline & & ROC & TSP & & & \\
\hline \multicolumn{2}{|c|}{$\mathbf{T}$} & 0.15 & 0.18 & \multicolumn{3}{|c|}{0.16} \\
\hline \multicolumn{2}{|c|}{$\mathbf{A}$} & 0.18 & 0.21 & \multicolumn{3}{|c|}{0.20} \\
\hline \multicolumn{2}{|c|}{ AT } & 0.27 & 0.31 & \multirow{2}{*}{\multicolumn{3}{|c|}{0.29}} \\
\hline \multicolumn{2}{|c|}{ MeanPhosphate fertilizer } & 0.20 & 0.24 & & & \\
\hline \multirow{2}{*}{\multicolumn{2}{|c|}{ Bio-fertilizer) B( }} & organi & terial & \multirow{2}{*}{\multicolumn{3}{|c|}{ Mean Bio-fertilizer }} \\
\hline & & OM0 & OM1 & & & \\
\hline \multicolumn{2}{|c|}{$T$} & 0.15 & 0.18 & \multicolumn{3}{|c|}{0.16} \\
\hline \multicolumn{2}{|c|}{$\mathbf{A}$} & 0.19 & 0.21 & \multicolumn{3}{|c|}{0.20} \\
\hline \multicolumn{2}{|c|}{ AT } & 0.27 & 0.31 & \multirow{2}{*}{\multicolumn{3}{|c|}{0.29}} \\
\hline \multicolumn{2}{|c|}{ Mean organic material } & 0.20 & 0.23 & & & \\
\hline B OM P & B OM & B P & $\mathbf{P}$ & $\mathbf{O M}$ & B & LSD \\
\hline 0.02 & 0.02 & 0.02 & 0.01 & 0.01 & 0.01 & 0.05 \\
\hline
\end{tabular}


Table.4 The effect of bio-fertilizers and phosphate and organic material content in the shoot of the phosphorus $\%$ at end of season

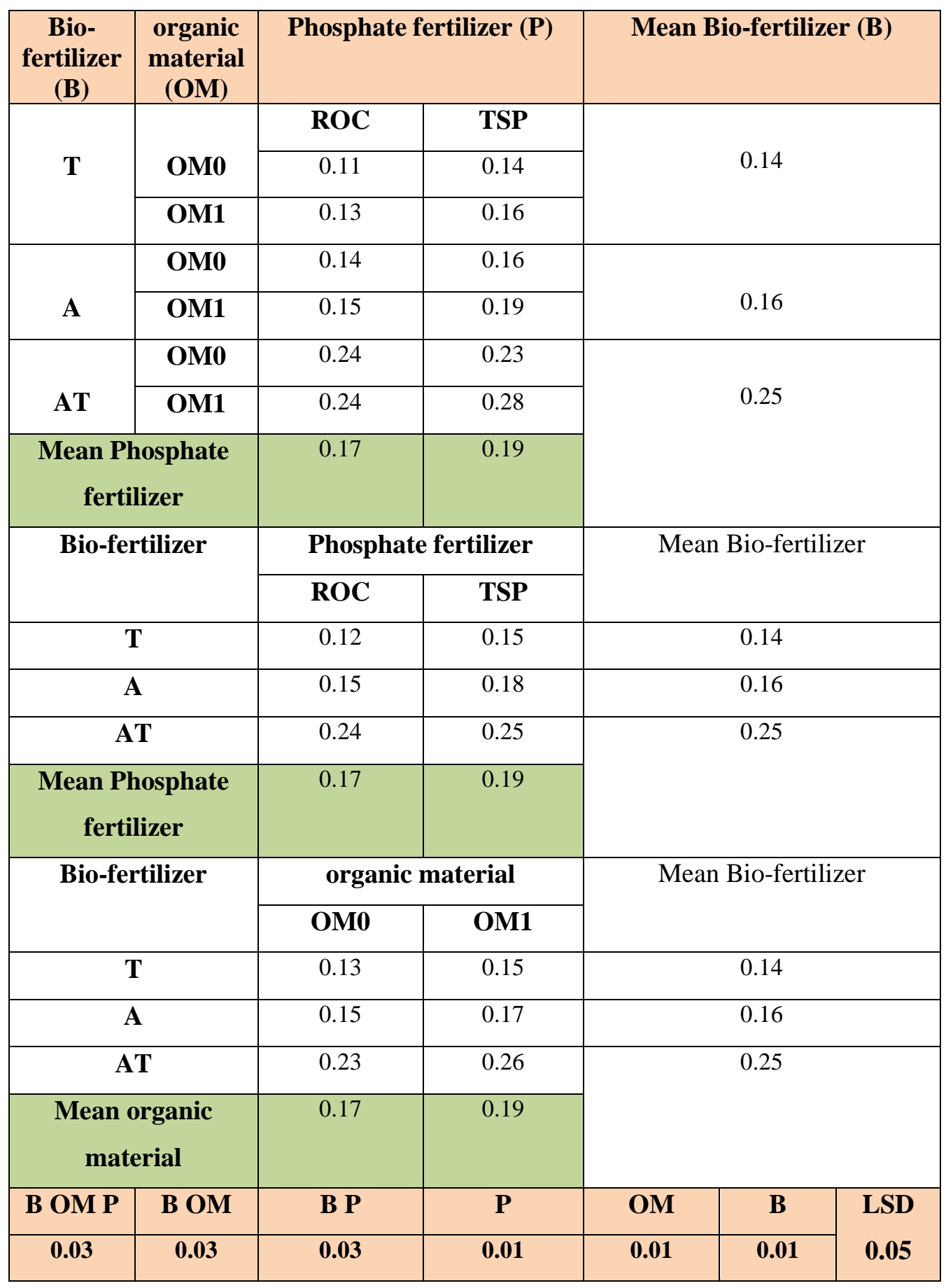


Table.5 The impact of bio-fertilizers and phosphate and organic material in the soil content of phosphorus mg. p. Kg-1 (mid-season)

\begin{tabular}{|c|c|c|c|c|c|c|}
\hline \multirow{2}{*}{$\begin{array}{c}\text { Bio- } \\
\text { fertilizer } \\
\text { (B) }\end{array}$} & \multirow{2}{*}{$\begin{array}{l}\text { Organic } \\
\text { material } \\
(\mathrm{OM})\end{array}$} & \multicolumn{2}{|c|}{$\begin{array}{l}\text { Phosphate fertilizer } \\
\text { (P) }\end{array}$} & \multirow{2}{*}{\multicolumn{3}{|c|}{ Bio-fertilizer (B) Mean }} \\
\hline & & ROC & TSP & & & \\
\hline \multirow[b]{2}{*}{$\mathbf{T}$} & OM0 & 29.58 & 31.89 & \multirow{2}{*}{\multicolumn{3}{|c|}{31.43}} \\
\hline & OM1 & 31.68 & 32.56 & & & \\
\hline \multirow[b]{2}{*}{$\mathbf{A}$} & OM0 & 36.97 & 39.56 & \multirow{2}{*}{\multicolumn{3}{|c|}{39.31}} \\
\hline & OM1 & 39.38 & 41.4 & & & \\
\hline \multirow[b]{2}{*}{ AT } & OM0 & 43.20 & 47.21 & \multirow{2}{*}{\multicolumn{3}{|c|}{46.66}} \\
\hline & OM1 & 46.08 & 50.16 & & & \\
\hline \multicolumn{2}{|c|}{$\begin{array}{l}\text { Mean Phosphate } \\
\text { fertilizer }\end{array}$} & 37.80 & 40.44 & & & \\
\hline \multirow{2}{*}{\multicolumn{2}{|c|}{ Bio-fertilizer (B) }} & \multicolumn{2}{|c|}{$\begin{array}{l}\text { Phosphate fertilizer } \\
\text { (P) }\end{array}$} & & & \\
\hline & & ROC & TSP & & & \\
\hline \multicolumn{2}{|c|}{$\mathrm{T}$} & 30.63 & 32.22 & \multicolumn{3}{|c|}{31.43} \\
\hline \multicolumn{2}{|c|}{$\mathrm{A}$} & 38.15 & 40.48 & \multicolumn{3}{|c|}{39.31} \\
\hline \multicolumn{2}{|c|}{ AT } & 44.64 & 41.37 & \multirow{2}{*}{\multicolumn{3}{|c|}{46.66}} \\
\hline \multicolumn{2}{|c|}{$\begin{array}{l}\text { Mean Phosphate } \\
\text { fertilizer }\end{array}$} & 37.8 & 40.44 & & & \\
\hline \multirow{2}{*}{\multicolumn{2}{|c|}{ Bio-fertilizer (B) }} & orga & aterial & \multirow{2}{*}{\multicolumn{3}{|c|}{ Bio-fertilizer (B) Mean }} \\
\hline & & OM0 & OM1 & & & \\
\hline \multicolumn{2}{|c|}{$\mathrm{T}$} & 30.74 & 32.12 & \multicolumn{3}{|c|}{31.43} \\
\hline \multicolumn{2}{|c|}{ A } & 38.23 & 40.39 & \multicolumn{3}{|c|}{39.35} \\
\hline \multicolumn{2}{|c|}{$\mathrm{AT}$} & 45.2 & 48.12 & \multirow{2}{*}{\multicolumn{3}{|c|}{46.64}} \\
\hline \multicolumn{2}{|c|}{$\begin{array}{c}\text { Mean organic } \\
\text { material }\end{array}$} & 38.06 & 40.21 & & & \\
\hline B OM P & B OM & B P & $\mathbf{P}$ & OM & B & LSD \\
\hline 5.09 & 3.69 & 7.04 & 0.02 & 2.07 & 2.54 & 0.05 \\
\hline
\end{tabular}


Table.6 Bio-fertilizers, phosphate and organic material in the soil content of phosphorus ready phosphorus mg. p. $\mathrm{Kg}-1$ (end of season)

\begin{tabular}{|c|c|c|c|c|c|c|}
\hline \multirow{2}{*}{$\begin{array}{c}\text { Bio } \\
\text { fertilizer } \\
\text { (B) }\end{array}$} & \multirow{2}{*}{$\begin{array}{c}\text { organic } \\
\text { material } \\
(\mathrm{OM})\end{array}$} & \multicolumn{2}{|c|}{ Phosphate fertilizer (P) } & \multicolumn{3}{|c|}{ Mean Bio-fertilizer } \\
\hline & & ROC & TSP & & & \\
\hline \multirow[t]{2}{*}{$\mathbf{T}$} & OMo & 21.54 & 22.57 & \multirow{2}{*}{\multicolumn{3}{|c|}{22.4}} \\
\hline & OM1 & 21.83 & 23.67 & & & \\
\hline \multirow[t]{2}{*}{$\mathbf{A}$} & OM0 & 25.25 & 28.25 & \multirow{2}{*}{\multicolumn{3}{|c|}{27.64}} \\
\hline & OM1 & 27.44 & 29.61 & & & \\
\hline \multirow[t]{2}{*}{ AT } & OM0 & 35.29 & 37.84 & \multirow{3}{*}{\multicolumn{3}{|c|}{37.28}} \\
\hline & OM1 & 37.64 & 40.35 & & & \\
\hline \multicolumn{2}{|c|}{ Mean Phosphate fertilizer } & 28.16 & 30.38 & & & \\
\hline \multirow{2}{*}{\multicolumn{2}{|c|}{ Bio-fertilizer (B) }} & Phosph & lizer (P) & \multirow{2}{*}{\multicolumn{3}{|c|}{ Mean Bio-fertilizer }} \\
\hline & & ROC & TSP & & & \\
\hline \multicolumn{2}{|c|}{$\mathbf{T}$} & 21.68 & 23.12 & \multicolumn{3}{|c|}{22.4} \\
\hline \multicolumn{2}{|c|}{$\mathbf{A}$} & 26.34 & 28.93 & \multicolumn{3}{|c|}{27.64} \\
\hline \multicolumn{2}{|c|}{$\mathbf{A T}$} & 36.46 & 39.1 & \multirow{2}{*}{\multicolumn{3}{|c|}{37.78}} \\
\hline \multicolumn{2}{|c|}{ Mean Phosphate fertilizer } & 28.16 & 30.38 & & & \\
\hline \multirow{2}{*}{\multicolumn{2}{|c|}{ Bio-fertilizer (B) }} & organic & l (OM) & \multirow{2}{*}{\multicolumn{3}{|c|}{ Mean Bio-fertilizer }} \\
\hline & & OMo & OM1 & & & \\
\hline \multicolumn{2}{|c|}{$\mathbf{T}$} & 22.05 & 22.75 & \multicolumn{3}{|c|}{22.4} \\
\hline \multicolumn{2}{|c|}{$\mathbf{A}$} & 26.75 & 28.52 & \multirow{3}{*}{\multicolumn{3}{|c|}{$\frac{21.04}{37.78}$}} \\
\hline$\overline{\mathbf{A}^{\prime}}$ & & 36.57 & 38.99 & & & \\
\hline \multicolumn{2}{|c|}{ Mean organic material } & 28.46 & 30.09 & & & \\
\hline B OM P & В OM & B P & $\mathbf{P}$ & $\mathbf{O M}$ & B & LSD \\
\hline 1.51 & 7.21 & 1.53 & 0.61 & 0.61 & 0.75 & 0.05 \\
\hline
\end{tabular}

Phosphorus sedimentation gained much attention in recent years, particularly in calcareous soils because they are important to know the fate of phosphate fertilizers added to the soil. Both Amedei, 2000 that structure calcium phosphate is controlling the solubility of phosphorus in soil and trans formed overtime in to phosphate formula eight calcium Rahi et al., 1994. People had high attention to Know soil Microbiology since the dawn of history. Results showed interaction between bio-Fertilizer and organic material and the presence of a significant increase in the soil content of phosphorus availability reaching proportions in the middle of season $30.74,38.23,45.20$,

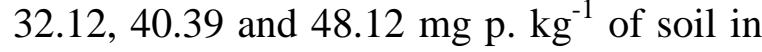
treatment T. OM0, AOM0, AT OM0, TOM1, AOM1 and AT. OM respectively and excelled treatment AT.OM1 significantly on treatment A.OM0 also there was a significant difference between two treatment AT.OM0 and AOM0 AS to the end of the season reaching ratios 22.05, $26.75 ; 36.57 ; 22.75 ; 28.52$; and $38.99 \mathrm{mg}$ p. $\mathrm{kg}^{-1}$ of soil in treatments T.OM0, A.OM0, AT.OM0, TOM1, AOM1 and ATOM1 respectively. Excelled or superior treatment AT significantly on OM1treatment AOM0.Result show the role of organic material to increase the proportion of the availability of phosphorus in the soil where the presence of organic material stimulates and activates of microorganisms moisture and also contain the sources of carbon and energy to do its part in the Liberation of phosphorus as well to contain organic materials the ratio of phosphorus availability Khan, 2001 Ali and Ahmed, 2000. The reason for this increase in the proportion of 
phosphorus back to the organic acid secreted by fungus as well as organic acid formed by organic materials has great role in reducing the $\mathrm{pH}$ of soil which has the main and the big role in crease the solubility and availability chattha et al., 2007; yalda, 1995; Turan et al., 2007. The triple overlap between chemical fertilizer and organic material and phosphate fertilizer showed significantly increased in the soil content of phosphorus ready if hit ratios in the middle of the season $43.08 \mathrm{mg} \mathrm{kg}-1$ and soil $\mathrm{kg}-1$ and $47.21 \mathrm{mg} \mathrm{P}$, for the treatments AT OMO ROK \& AT ROK OM1 \& ATOMO TSP \& AT OM1 TSP regularly. The third treatment ATOM1 TSP was morally particularize on the treatment AT OMO ROK. At the end of the season the ratios were $35.79 \mathrm{mg} \mathrm{P}$ for 1 $\mathrm{Kg}$ of soil-1 \& 37.64 for $1 \mathrm{Kg}$ of soil-1 \& 37.84 for $1 \mathrm{Kg}$ of soil-1\& 40.35 for $1 \mathrm{Kg}$ of soil-1 for the treatments AT OMO ROK AT ROK OM1 \& ATOMO TSP \& AT OM1 TSP regularly. The treatment ATOM1 TSP was morally particularize excelled the treatment AT OMO ROK.From these results we infer the role of the overlap between the type of microorganism and the type of source of phosphate and add or not to add organic material to improve the solubility and readiness of phosphorus. The presence of organic material is a source of energy and carbon to increase the number of Microbiology and the growth of fungi, including increasing its effectiveness and then secrete enzymes such as Alkaline enzyme and Phytase and secretion of organic acids which lead to increased readiness of phosphorus.And secretion of organic acids which lead to increased readiness of phosphorus from two different sources are rock phosphate and fertilizer Super triple superphosphate was to revive an important role in the processing of soil element phosphorus by dissolving phosphorus rock phosphate, a crude fertilizer, which reduces agricultural production costs, which improves living situation of farmer and citizen's pension by reducing the cost unit of productivity and fungi lead to increased concentration of phosphorus in the soil. The secretion organic acids which lead to increase the concentration of phosphorus in the soil.Velazqnez et al., (2005) found that the effect will be multiplied in the melt phosphate rock and improve plant growth when using mushroom Trchoderma and ASpergillus fertilizer lively with plant tomato and microbiology have the ability to dissolve the third part of the chemical fertilizers and phosphate deposited in the soil (Mukhaimar, 2008) and Aiza the presence of organic matter in the soil leads to reduced adsorption of phosphorus in the soil And it attributed the melting.

\section{References}

Achal, V. 2005. Solubilization of phosphate Rocks and Minerals by wild type and UVinduced Mutants of Aspergillustubingensis. M.S. Department of Biotechnology and Environmental Sciences Thapar institute of Engineering and Technology Patiala - 147004.

AL Naimi, S.N.A. 1999. Fertilizer and soil fertility.The Ministry of Higher Education and Scientific Research. University of Al Mosul. National Library for printing.

Ali, N.C., N.N. Ahmed. 2000. Adsorption and precipitation of phosphorus in calcareous soils of central Iraq. Iraqi J. Sci. Alzeraih, cild (31). Issue (2): 91-118.

Alikhani, H.A., N. Saleh-Rastin, H. Autoun. 2006. Phosphate solubilization activity of rhizobia native to Iranian soils. Plant and Soil, 287: 35-41.

Altomare, C., W.A. Norvel, T. Bjorjman. and G.E. Harman. 1999. Solubilization 
of phosphate and micronutrients by the plant growth promoting and biocontrol fungus Trichodermaharzianum. Rifai 1295-22. Appl. Environ. Microbiol., 65: 2926-2933.

Amedei, P.M.S. 2000. Indicators Readiness and thermodynamic parameters of the adsorption and the start of phosphate in soils of limestone.Master Thesis, College of Agriculture, University of Dohuk.

Deepa, V., A. Prasanna, B., Murthy and R. Sridhar. 2010. Efficient Phosphate Solubilization by Fungal Strains Isolated from Rice-rhizosphere Soils for the Phosphorus Release. J. Agri. Biol. Sci., 6(4): 487-492

Fadol, G.T., W. Nafa. 2009. mycology. Damascus University publications, Faculty of Agricultural Engineering.

Hamza, M., S. Khoufi and S. Sayadi. 2012. Fungal enzymes as a Powerful tool to release antioxidants from olive mill Wastewater. Volume 131, Issue 4, Pages 1430-1436.

Harman, G.E. 2000. Myths and dogmas of biocontrol-plant Disease. 84(4): 377393.

Havlin, J.L., J.D. Beaton, S.L. Tisdale, W.L. Nelson. 2005. Soil fertility and fertilizers, An Introduction to Nutrient Management, $7^{\text {th }}$ ed, Upper Saddle River New Jersey. USA. p.515.

Hoflich, G., W. Wichc, and G. Kuhn. 1994. Plant growth stimulation by inoculation with symbiotic and associative rhizosphere microorganisms. Experientia, $50: 897$ -905 .

Hosseny, M.H. and M.M.M. Ahmed. 2009. Effect of nitrogen organic and biofertilization on productivity of letture (c.v.Romane) in sandy soil under Assiut conditions. Assiutunviv. Bull. Environ. Res., 12: 79-93.

Illmer, P., Barbato, A. and Schinner, F.
1995. Solubilization of hardly soluble AIPO 4 with P-solubilizing microorganisms. Soil Biol. Biochem., 27: 265-270.

Khan, M.R. and S.M. Khan. 2001. Biomanagement of Fusarium wilt of tomato by the soil application of certain phosphate - solubilizing microorganisms. Int. Pest Mange, 47(3): 277-231.

Kumari, A.K., K. Kapoor, B., S. Kundu and R.K. Mehta. 2008. Identification of organic acids produced during rice straw decomposition and their rolein rock phosphate solubilization. Plant Soil.

Li, R.X., F. Cai, G. Pang, Q., Shen, R., Li, R., and W. Chen. 2015. Solubilisation of phosphate and micronutrients by Trichodermaharzianum and its relationship with the promotion of tomato plant growth. PloS one, 10(6): $\mathrm{e} 0130081$.

May Thet New, San San Yu, and ZawKo Latt. 2013. Study on Phosphate Solubilization of Salt Tolerant Soil Yeast Isolates and Effects on Maize Germination and Growth. Int. J. Innovation and Appl. Studies, ISSN 2028-9324 Vol. 4 No. 3 Nov, pp. 524533.

May, T.N.S. and Z.K. Latt. 2013. Study on Phosphate Solubilization of Salt Tolerant Soil Yeast Isolates and Effects on Maize Germination and Growth. Int. J. Innovation and Appl. Studies, ISSN 2028-9324 Vol. 4 No. 3 Nov, pp. 524-533.

Mehta, S. and Nautiyal, C.S. 2001. An efficient method for qualitative screening of phosphatesolubilizing bacteria. Curr. Microbiol., 43: 51-56.

Mukhaimar, G.A.A. 2008. ohmah the use of bio-fertilizers in agriculture. Article, Ain Shams Magazine, Issue 91 JulyAugust of the Arab Republic of Egypt. 
Nautiyal, C.S. 1999. An efficient microbiological growth medium for screening phosphate solubilizing microorganisms. FEMS Microbiol. Lett., 170: 65-70.

Panda, R., S.P. Panda, R.N. Kar and C.R. Panda. 2011. Influence of Environmental Factors and SalInity on Phosphate Solubilization.

Pikovaskya, R.I. 1948. Mobilization of phosphorus in soil in connection with vital activity of some microbial species. Microbiologiya, 17: 362-370.

Promwee, A., Issarakraisila, M., Intana, W., Chamswarng, C. and, P. Yenjit. 2014. Phosphate solubilization and growth promotion of rubber tree (HeveabrasiliensisMuell. Arg.) by Trichoderma strains. J. Agri. Sci., 6(9): 8.

Qasim, M.G. and H.H.p. Alzendinyani. 2011. The role of fungi in dissolving rock phosphate and its effect on the growth of maize (Zea mays). Journal of agricultural land between the two rivers. Folder (39).Issue (3).College Agriculture and Forestry. University of Al Mosul.

Rahi, H.S., M.J. al-Obeidi and I. Ibrahim, Khader. 1994. L'impact des niveaux de soufreagricoleset des changementsd'humidité du sol sur le phosphoredans les conditions du sol calcaire, College of Agricultural Science, vol. 252, $\mathrm{n}^{\circ} 2$

Richa, G., B. Khosla and S. Reddy. 2007. Improvement of Maize plant Growth by phosphate solublizing fungi in Pock phosphate Amended soils. World J. Agri. Sci., 3(4): 481-484.

Rosen, C.J. and R. Eliason. 2002. Nutrient management for commercial fruit and vegetable crops in Minnesota. Univ. of Minnesota.

Saber, W.I.A., K.M. Ghanem and M.S. ELHersh. 2009. Rock Phosphate
Solubillization by Tow Isolates of Aspergillusniger and Penicillium sp. And their Promotion to Mung Bean Plants. Res. J. Microbiol., 4(7): 235250.

Tisdale, S.L. and W.L. Nelson. 1975. Soil Fertility and Fertilizers, 3rd.ed. New York, Macmillan Publ.

Turan, M., N. Ataoglu and F. Sahin. 2007. Effects of Bacllus S-3 on growth of tomato (Lycopersiconesculentum Mill) plants and availability of phosphorus in soil. Plant Soil Environ., 53(2): 58-64.

Vaddar, U.B. 2007. Studies on grape Rhizospheremicroorganisms. Master of Science (Agriculture). University of agricultural Sciences, DHARWAD580005.

Velazquez, M.S., L.A. Eliades, G.B. Irrazabal, C.M. Saparrat and M.N. Cabello. 2005. Mycobization with Glomusmosseae and Aspergillusniger in Lycopersicon esculentum plants. $J$. Agri. Technol., 1(2): 315- 326.

Whitelaw, M.A. 2000. Growth promotion of plants inoculated with phosphate solubilizing fungi. Adv. Agron., 69: 99-151.

Williams, E.G. 1959. Influence of parent material and drainage condition on soil phosphorus relationship. Agro. Chem., 3: 279 .

Yadav, J., J.P. Verma and K.N. Tiwari. 2011. Solubilization of Tricalcium phosphate by fungus Aspergillusniger at Different Carbon Source and Salinity. Trends in Appl. Sci. Res., 6(6): 606-613.

Yalda, B.D. 1995. Microbiology phosphate dissolving in readiness phosphorus effect. Master Thesis, College of Agriculture, University of Baghdad.

Yasser, M.M., Mousa, A.S., Massoud, O.N., and S.H. Nasr. 2014. Solubilization of inorganic phosphate by phosphate 
solubilizing fungi isolated from Egyptian soils. J. Biol. Earth Sci., 4(1): B83-B90.

Youssef, M.A., EL-Sayed, M.M., and I.I. Sadek. 2013. Impact of organic manure, bio-fertilizer and irrigation intervals on wheat growth and grain yield. Am. Eur. J. Agric. Environ. Sci., 13: 1488-1496.

\section{How to cite this article:}

Haider A. Fadhl and Bahaa A.A. Al-Hadithi. 2016. The Effect of Fungi Inoculation Solvent Phosphate in Increasing Phosphorus availability in Calcareous Soil and its Concentration in Cucumis sativus L. Int.J.Curr.Microbiol.App.Sci. 5(8): 750-763.

doi: http://dx.doi.org/10.20546/ijcmas.2016.508.086 